\title{
A Clinical Study on Medovridhhi (Hyperlipidemia) and its Management with Eranda Kshara Yoga
}

\author{
Dr. Sushanta Sahu ${ }^{\text {, Dr. Binod Kumar Panda }}{ }^{2}$ \\ ${ }^{1}$ P.G. Scholar, Department of Kayachikitsa, Gopabandhu Ayurveda Mahavidyalaya, Puri, Odisha, India \\ ${ }^{2}$ Professor \& Head, Department of Kayachikitsa, Gopabandhu Ayurveda Mahavidyalaya, Puri, Odisha, India
}

\begin{abstract}
Medovridhhi is a disorder of medovahasrotas as per Ayurvedic concept with symptoms of deposition of meda at the site of abdomen, buttack, chest, arm, thigh, neck, and all over body. As per modern concept it can be correlate with Hyperlipidemia. Hyperlipidemia is a disorder of lipid metabolism manifested by elevation of plasma concentration of the various lipids and lipoproteins fraction, which is the key risk factor for all the life threatening diseases like cardio vascular disease, diabetes, hypertension etc., ., since synthetic drugs have been shown to have side effect, clinical importance of herbal drugs in the treatment of hyperlipidemia has receive considerable attention in recent years. Hence the proposed study was undertaken to investigate and establish the antihyperlipidemic effect of a herbal compound "ErandaKshara yoga" prepared by using the above two medicinal plant Eranda and Hingu with textual reference from Bhaishajya Ratnavali (Medorogadhikar). The final result and outcome of the study will be incorporated in the thesis after completion of study with a hope that it will be benefited to the mankind.
\end{abstract}

Keywords: Medovridhhi, Ayurvedic, Hyperlipidemia, Eranda Kshara Yoga

\section{Introduction}

Medovridhhi is a disorder of medovahasrotas as per Ayurvedic concept with symptoms of deposition of meda at the site of abdomen, buttack, chest, arm, thigh, neck, and all over body. The associated symptoms like chalasphikudarastana, kshudraswasha, pipasatiyoga, kshudhatimatra, swapna, kshavathu, dourgandha, dourbalya etc. are also found in this condition. ${ }^{1,2}$ As per modern concept it can be correlate with Hyperlipidemia. Hyperlipidemia is a disorder of lipid metabolism manifested by elevation of plasma concentration of the various lipids and lipoproteins fraction, which is the key risk factor for all the life threatening diseases like cardio vascular disease, diabetes, hypertension etc., since synthetic drugs have been shown to have side effect, clinical importance of herbal drugs in the treatment of Hyperlipidemia has receive considerable attention in recent years. The drug Eranda (Ricinus communis) and Hingu(Ferula narthex) use as antihyperlipidemic drugs i.e. medoharadravya as per Ayurvedic literature. The animal study on Ricinus communis and Ferula narthex shows antihyperlipidemic effect. ${ }^{3,4}$ Hence the proposed study was undertaken to investigate and establish the antihyperlipidemic effect of a herbal compound "Eranda Kshara yoga" prepared by using the above two medicinal plant Eranda and Hingu with textual reference from Bhaishajya Ratnavali(Medorogadhikar). ${ }^{5}$

\section{Epidemiology \& Surveillance}

The Indian Council of Medical Research (ICMR) surveillance project reported a prevalence of Hyperlipidemia of $37.5 \%$ of adult between age group of 20-60 years. WHO in 2002 reported that Hyperlipidemia is one of the major non communicable disease related risk factor in India?

National Commission on Macro-economic \& Health(NCMH) in India has estimated that by 2015 approx.
62 million of Indian population will developed CAD due to dislipidemia out of 23 million will be less than 40 years. ${ }^{6}$

\section{Previous Research Works}

1) Prusty Dr. Umesh Chandra :- Concept of medoroga visà-vis hyperlipidemia and its management with Nawaka guggulu- M.D. thesis G.A.M., Puri-1984

2) Prasad Dr. Nagendra :- "A study on Medovridhhi and its Management with Medohar Arka"- M.D. thesis G.A.M., Puri-2003

3) Mishra Dr. Sriram Chandra :- Study on Virechana with special reference to Medoroga(Obesity)- M.D. thesis G.A.M., Puri-2006

4) Nawja Dr. Prajwal :- Clinical study to evaluate the efficacy of Vamana in Medoroga w.r.t. Obesity - M.D. thesis RGUHS, Bangalore- 2008

5) D. sagar. C., Shah Nirzarini N.,Sachadeva PunamD.,Patel Nikunj d.,Jani Dillip K. :- "Study on poly Herbal compound containing Ricinus communis to control Hyperlipidemia in rats- Enthropharmacology Vol-2011/255/10

6) Savjani R, Baghel MS. A clinical study on the management of Sthaulya by Panchtikta and LekhanaBasti - MD Thesis,IPGT\&RA, 2001.

7) EmanG.E.Helal and Mohamed M. A. Shahat:Hypolipidimic effect of some medicinal plants containing Ferula narthex on diabetic rats - The Egyptian Journal of Hospital Medicine Vol., 23: 200 - 211 June 2006

\section{Intension of the Study}

All though various research work conducted earlier in Medoroga and Medovridhhi(Hyperlipidemia), I have select this for research as it is the burning disease of the today's society having a high incidence rate in high economic group with sedentary lifestyle. The trial drug chosen by me contain Ricinus communis and Ferula narthex shows antihyperlipidemic result in experimental animal. The 


\section{International Journal of Science and Research (IJSR) \\ ISSN (Online): 2319-7064}

Index Copernicus Value (2013): 6.14 | Impact Factor (2014): 5.611

toxicity study of Ricinus communis suggest that Ricin from seed and root is somehow toxic ${ }^{7}$ not the leaves ${ }^{8}$ and Ferula narthex also proved to be non-toxic. ${ }^{9,10}$ So to establish the antihyperlipidemic effect of the combine formulation in human trial, I have taken the propose study for my clinical research.

\section{Aim}

Keeping all the fact in mind I have taken up the proposed study on "A clinical study on Medovridhhi(Hyperlipidemia) and its management with Eranda Kshara Yoga”.

\section{Objective}

1) Review of literature regarding Medovridhhi with respect to Hyperlipidemia.

2) Therapeutic evaluation of trial drug i.e. Eranda kshara yoga as compare to standard control drug Rosuvastatin.

\section{Hypothesis}

"Eranda Kshara Yoga" is effective in case of Medovridhhi (Hyperlipidemia) and can effectively control the clinical condition associated with this disease (BhaishajyaRatnavaliMedorogadhikar -20)

\section{Material and Method}

Following the criteria of selection, 60 cases of hyperlipidemic patients shall be selected for the propose study.

\section{Selection Criteria}

\section{Inclusion Criteria}

- Age- 20 - 60 years

- Sex- Both the sexes

- Patient having the classical sign and symptoms of Hyperlipidemia.

- B.M.I. within $25-39.9 \mathrm{~kg} / \mathrm{mt}^{2}$

- Skin fold thickness - male $>40 \mathrm{~mm}$, female $>50 \mathrm{~mm}$

\section{Exclusion Criteria}

- Age below 20 years and above 60 years

- Patient having any other systemic disorder and complications.

- Patient having severe diabetes and heart diseases.

- Hereditary origin and endocrinal involvement.

- Case having medical emergencies.

- B.M.I. $>40 \mathrm{~kg} / \mathrm{mt}^{2}$

- Pregnant women

\section{Diagnostic Investigation}

\section{Lipid profile}

1) Total serum Cholesterol

2) Triglyceride

3) Low density lipid(LDL)

4) High density lipid(HDL)

5) Very low density lipid(VLDL)

\section{Methodology}

The study will be initiate with literary review of disease and the drug with reference to Ayurvedic concept and modern concept. Thus the help of reference books, past research works, various journals and internet will be taken. The trial drug will be given to patient after analytical study of the prepared drug in an authorized drug testing laboratory. For clinical trial 60 patient will be selected and divided in to two groups'.viz-

1)Group-I - Trial group- 30 patients, will treated with Eranda Kshara Yoga

2)Group-II - Control group-30 patients, will be treated with standard control Drug Rosuvastatin.

Both the group under study shall keep under supervision and monitor properly and should follow the instructed diet and regimen. Progression of sign and symptoms will be monitor in every 30 days intervals.

\section{Drug and Dose}

The trial drug "Eranda Kshara Yoga" will be prepared in G.A.M., Pharmacy attached to P.G. Dept. of R.S. \& B.K. by combination of Eranda kshara prepared from leaves of Eranda and purified Hingu in equal quantities. Kshara is made as per kshara paka method and Hingu is purified by frying in cow ghee. Dose is fixed as per textual references.

1) Trial drug :- Eranda kshara yoga- in Capsule form 500 mg twice daily after food with warm water.

2) Control drug:- Tab. Rosuvastatin- 10 mg- 1 tab. Once daily after food preferably at night.

\section{Place of Study}

1) Gopabandhu Ayurveda Mahavidyalaya\& Hospital, Puri

2) Dist. Head Quarter Hospital, Puri.

3) Analytical study will done in a standardized Drug Testing Laboratory.

\section{Duration of Study}

Both the groups under study exposed to the respective treatment for a period of 3 months and follow up will given in every one month interval.

\section{Plan and Protocol of the Study}

Multi group design will be undertaken to correlate the clinical effect of control and trial drug as well as effect of drug before and after treatment.

\section{Design}

Single group design

\begin{tabular}{|c|c|c|}
\hline Group-I & B.T -vrs- A.T. & $\begin{array}{c}\text { Effectiveness of Eranda Kshara } \\
\text { Yoga will be assessed }\end{array}$ \\
\hline $\begin{array}{c}\text { Group- } \\
\text { II }\end{array}$ & B.T. - -vrs- A.T. & $\begin{array}{c}\text { Effectiveness of standard control } \\
\text { drug will be assessed }\end{array}$ \\
\hline
\end{tabular}

Double group design

\begin{tabular}{|l|l|}
\hline Group-I - vrs - Group-II & $\begin{array}{l}\text { Effectiveness of Eranda Kshara } \\
\text { Yoga with respect to Rosuvastatin } \\
\text { will be assessed. }\end{array}$ \\
\hline
\end{tabular}




\section{Ethical Review}

Ethical clearance has all ready being obtained from the Institutional Ethical Committee (IEC) of Gopabandhu Ayurveda Mahavidyalaya \& Hospital, Puri, Odisha

\section{Assessment}

Assessment will be made following the progress in subjective and objective criteria.

\section{Conclusion}

The effects of the study will assume to fruitful the demand of the society to maintain a healthy life style and the drug is assume to be effective in the management of Hyperlipidemia. The exact result and conclusion will be drawn after completion of the trial.

\section{References}

[1] Tripathi R.D :- CharakSamhita-choukhamba Sanskrit Pratisthan- 2007 edn

[2] Shastri Ambika Dutt :- SushrutaSamhitachoukhambasanskritsasthan, 2009 edn.

[3] Dadhawin sagar. C. etal, :- - "Study on poly Herbal compound containing Ricinus communis to control hyperlipidemia in rat"-Enthropharmacology Vol2011/255/10

[4] Eman G. E. Helal and Mohamed M. A. Shahat:Hypolipidimic effect of some medicinal plants containing Ferula narthex on diabetic rats - The Egyptian Journal of Hospital Medicine Vol., 23: 200 211 June 2006.

[5] Mishra S.N. :- Bhaishajyaratnavali- Medoroga Prakaran sloka no-20-

[6] Choukhambasurbharati prakashan-2009 edn.

[7] Y.P.Munjal :- API text book of Medicine $-9^{\text {th }}$ Edn.2012

[8] Wikipedia \& Journal of Cornell University, Dept. of Animal science.

[9] PingaleShirishSadashiv:- Acute toxicity study for Ricinus Communis:- Scholar Research Library2011:3(5) 132-137- ISBN 0975-5071

[10] Milard Iranshahy, Mehrdad Iranshahi:- Traditional uses, phyto-chemistry and pharmacology of Asa foetida- A review:- Journal of Ethno pharmacology- Vol.134, 6 march 2011, pg-1-10

[11]Eli Kassis, Stephen Fulder and co. :- Efficacy and safety assessment of Ferula asa foetida L.- Theopen Complementary Medicine Journal, 2009, 1,102-109

[12] Prasad. N :- G.A.M., Puri-2003 "A study on Medovridhhi and its Management with Medohar Arka" 